Strong, L. W.-The Preparation and Use of Thrombo-kinase. "Laryngoseope," February, 1911, p. 81.

This is a dry powder prepared by the precipitation of a saline tissue extract (in this case from ling) with acetic acid. It, if applied locally, promotes clotting, and hence arrest of hæmorhage. The author states that it has been used successfully in bleeding from the tonsil, but details are not given. Its action is probably due to the presence of a ferment. John Wright.

\title{
OBITUARY NOTICE.
}

T. G. Ouston, F.R.C.S.Eng.,

Surgeon, Throat, Nose, and Ear Hospital, and Hospital for Sick Children, Neweastle-on-Tyne.

WE regret to amnounce the death, on August 1, of Mr. T. G. Ouston, widely known as one of the most prominent north-country representatives of our speciality.

Mr. Ouston, having passed through his medical curriculum at Guy's Hospital and at the Yorkshire College, Leeds, acquired in 1891 the diplomas of L.R.C.P. and M.R.C.S. In 1894 he became a Fellow of the Royal College of Surgeons, England, and in the following year began his career in Neweastle-on-Tyne as a general practitioner. After having accumulated much valuable experience in general medicine he began to direct his activities to diseases of the throat, nose, and ear, and, at the time of his demise, occupied the post of surgeon to the Neweastle Throat and Ear Hospital, and had built up a considerable private practice as a specialist.

Mr. Ouston's was a familiar figure at the meetings of the Newcastle Medical Society, where his work and opinions were highly appreciated by all his fellow members. The last weeks of his life were occupied in the preparation of a paper dealing with the action of radium in the treatment of lupus and other diseases of the nose and throat. This paper he had intended to read at the recent meeting of the British Medical Association at Birmingham, but the intervention of the illness that was destined to end his life prevented his intentions being carried into effect. And it has been reserved to the Journal of Laryngology, Rhinologr, and OтоLogr to publish in the present issue this last effort of his scientific energy.

Mr. Ouston died at the too early age of forty-two years, only six months after his marriage, and at the zenith of a career full of success, usefulness, and popularity.

\section{BOOK RECEIYED.}

Handbuch der Speciellen Chirurgie des Ohres und der oberen Juftwege. Herausgegeben von Dr. L. Katz, Dr. H. Preysing, und Dr. F'. Blumenfeld. Bd. iii, Lieferung 1 and 2. Wïrzburg: Curt Kabitsch (A. Stuber's Verlag), 1911. 